$\underline{\text { Research Article }}$

\title{
INVESTIGATION OF RENEWABLE ENERGY USE IN THE P2X TECHNOLOGY
}

\author{
NIMA NOROUZI'1 \\ 1Department of Energy Engineering and Physics, Amirkabir University of Technology (Tehran Polytechnic), 424 Hafez Avenue, P0, Box \\ 15875-4413, Tehran \\ Email: nima1376@aut.ac.ir \\ Received: 17 Sep 2021 Revised and Accepted: 06 May 2021
}

\begin{abstract}
Objective: The electricity-to-hydrogen technology can convert surplus renewable energy electric energy into chemical energy. Hydrogen plays an important role in transportation, power generation, and other fields. Therefore, developing electrochemical (P2X) technology for renewable energy consumption effectively solves renewable energy curtailment.

Methods: The four aspects of market scale, technical route, energy conversion efficiency, and demonstration project progress are reviewed, and the energy efficiency of the four electrochemical technologies is compared, Power consumption, marginal electricity price, equivalent output, and market share five major technical and economic indicators. To analyze the strengths, weaknesses, opportunities, and threats of P2X in China, a literature review survey was conducted, relying on recent two-decade publications from four main publishers: Scopus, Springer, Wiley, and Taylor and Francis. Keywords were selected from the first-hand references based on their impact on P2X or related topics listed in the literature databases. The keywords as Power to X, Power to chemicals, PtX, and P2X were chosen according to their actual involvement or keen interest in P2X projects.

Results: The research results based on the low-temperature electrolysis technology route show that the comprehensive energy efficiency of the electricity-to-methane and electricity-to-gasoline technologies is higher (50\%); the electricity-to-gasoline technology is the most economical (marginal electricity price is 0.37 yuan/kWh), but the synthesis process requires carbon monoxide and carbon emissions, And the technical risk is high; the promotion of electricity to ammonia will have the greatest impact on the market (17.18\%). Reducing coal consumption by about 22.85 million tons and the environmental protection significance of electricity-to-ammonia conversion (reducing carbon emissions by about 39.1 million tons) are two important directions for future electrochemical technology.
\end{abstract}

Conclusion: Facing the development of P2X technology in the future, the plan and economics of the high-temperature electrical and chemical technology route based on high-temperature solid oxides were preliminary discussed and prospected.

Keywords: Renewable energy, Power to chemicals (P2X), Energy efficiency, Economic study

(C) 2021 The Authors. Published by Innovare Academic Sciences Pvt Ltd. This is an open-access article under the CC BY license (http://creativecommons.org/licenses/by/4.0/] DOI: http://dx.doi.org/10.22159/ijcr.2021v5i4.175. Journal homepage: https://ijcr.info/index.php/journal

\section{INTRODUCTION}

To respond to global warming caused by carbon emissions, ease the pressure on fossil energy supply, and ensure national energy security, China has actively promoted renewable energy represented by wind power, photovoltaics, and hydropower in recent years and promoted a cleaner energy consumption structure. Low-carbon transformation. In 2018, China's renewable energy power generation capacity was $1,776.4$ billion kWh, and the installed capacity was 711.15 million $\mathrm{kW}$, accounting for $26 \%$ and $38 \%$ of the total power generation and installed capacity, respectively. However, due to the volatility, randomness, and seasonal characteristics of renewable energy output, China's renewable energy curtailment reached 102 billion kWh in 2018, exceeding the Three Gorges Power Station [1, 2].

The electricity-to-hydrogen technology is an important technical means to realize large-scale renewable energy consumption [3]. Through the hardware system with the electrolytic cell as the core, electrical energy can be converted into chemical energy in hydrogen, used in subsequent diverse terminal applications such as chemical industry, transportation, power generation, heating, and gas storage [4, 5]. In addition, the load power of the electrolytic cell is relatively flexible, which can quickly track specific power adjustment commands and participate in grid dispatching as a flexible load resource, thereby improving grid flexibility and promoting renewable energy consumption [6, 7]. At present, electrolyzers based on low-temperature electrolysis technology (alkaline, proton exchange membrane) are relatively mature, and the single-stack power has reached megawatts level, and the comprehensive energy efficiency is $60 \% \sim 70 \%$ [8]. On the other hand, the high-temperature solid oxide electrolysis technology developed in recent years is expected to be more energy-efficient. Therefore, it is further increased to more than 85\% [9].

China's national and local governments have issued several support policies related to hydrogen energy [10]. In April 2016, the Energy Technology Revolution and Innovation Action Plan (2016-2030) jointly issued by the National Development and Reform Commission and the National Energy Administration listed Hydrogen Energy and Fuel Cell Technology Innovation as China's energy strategy, and the Government Work Report mentioned promoting the construction of charging and hydrogen refueling facilities [11]. Made in China 2025 report also puts forward a nationallevel plan for fuel cell vehicles, that is, to achieve the production of 1,000 fuel cell electric vehicles in 2020 and conduct demonstration operations [10]. However, currently limited by fuel cell technology, hydrogen energy in fuel cell-based transportation, power generation, and other fields is relatively small, and it is difficult to match the current level of renewable energy curtailment [12]. Relying on the huge potential of hydrogen application in the chemical industry at this stage, the development of power-to-X (P2X) technology for renewable energy consumption is another way to solve renewable energy curtailment [13]

In addition, in addition to the consumption of renewable energy, the P2X method is used to replace traditional fossil energy (such as coal chemical) production capacity. On the one hand, it can reduce fossil energy consumption and the emission of pollutants in fossil energy utilization and meet the low-carbon energy consumption of the chemical industry [11]. Sustained development needs; on the other hand, the use of power grids for energy transmission instead of traditional material transmission to realize the distribution and localization of chemical products can also reduce transportation time and costs to a certain extent, which is expected to reduce the terminal prices of chemical products further [14]. 
This article first starts with China's renewable energy curtailment and the foreseeable market scale in the hydrogen fuel cell field, analyzes the future demand for P2X technology, and then studies power-to-ammonia (P2A) and power-to-methane (P2CH4), power-to-methanol (P2CH3OH), and power-to-gasoline (P2G), which are the four major electrochemical technologies in market size, technical route, energy consumption, and Demonstration Project [9]. The technology and process of various P2X conversion equipment, including electricity to hydrogen, are still in the rapid development stage, and the cost of the equipment varies greatly. To clarify the advantages and disadvantages of different P2X technology routes, this article uses energy conversion efficiency and power consumption in the P2X process [7]. The main concern is the amount of energy. On this basis, the cost of the main raw materials (water, nitrogen, carbon monoxide, etc.) involved in the chemical reaction is considered, and the energy efficiency, power consumption, marginal price, equivalent output, and market share of the four P2X technologies are analyzed and calculated. Comparing five technical and economic indicators, combined with technological development, analyzes the feasibility and comprehensive social and economic benefits [10]. Facing the development of P2X technology in the future, a preliminary discussion and outlook on the technical route and economics of high-temperature electrochemical technology-based on high-temperature at the end of this paper, solid oxide, are carried out [8].

To analyze the strengths, weaknesses, opportunities, and threats of P2X in China, a literature review survey was conducted, relying on recent twodecade publications from four main publishers: Scopus, Springer, Wiley, and Taylor and Francis [13-16]. Keywords were selected from the firsthand references [17-19] based on their impact on P2X or related topics listed in the literature databases [6]. The keywords as Power to X, Power to chemicals, PtX, and P2X were chosen according to their actual involvement or keen interest in P2X projects.

\section{MATERIALS AND METHODS}

China's renewable energy curtailment has shown an overall upward trend in recent years, as shown in fig. 1.

According to the Blue Book of China's Hydrogen Energy Industry Infrastructure Development, the future development goals of China's hydrogen energy and fuel cell industry are shown in fig. 2 [11].

When designing classroom activities, teachers should go out of the form of group discussion and results from display to create problem-based, project-based, and task-based contextual activities for students [9]. The disconnect between the form and content of classroom activities and reality is the key factor that cannot attract students. When in a real situation, learners need to consider all real situations as a whole, not just focusing on a certain concept being learned [12]. A situation closer to life, more realistic problems, can stimulate learners' interest and encourage them to mobilize all their attention and devote themselves to corresponding activities. Teachers create a unique and pleasant learning experience for students in this link, and at the same time, can strengthen the teacher's professional identity [13].

In 2018, Japan's JGC company built a renewable energy-based electricity-to-ammonia demonstration plant at the Fukushima Renewable Energy Research Institute in Koriyama City, Fukushima Prefecture, with a production capacity of $20 \mathrm{~kg} / \mathrm{d}$. As a result, the corresponding renewable energy fluctuating output has been completed. Variable load synthetic ammonia operation test [14].

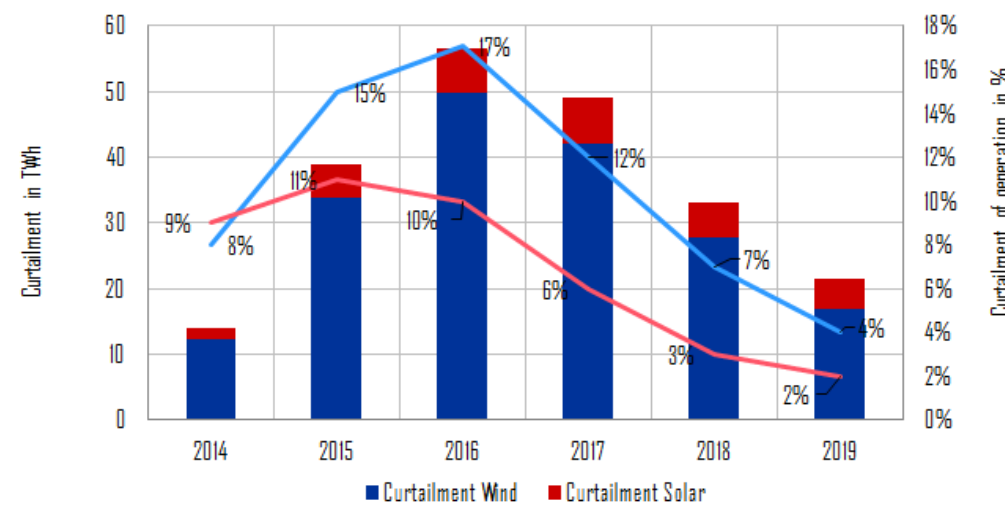

Fig. 1: China's renewable energy curtailment from 2011 to 2018 (adopted from [9])

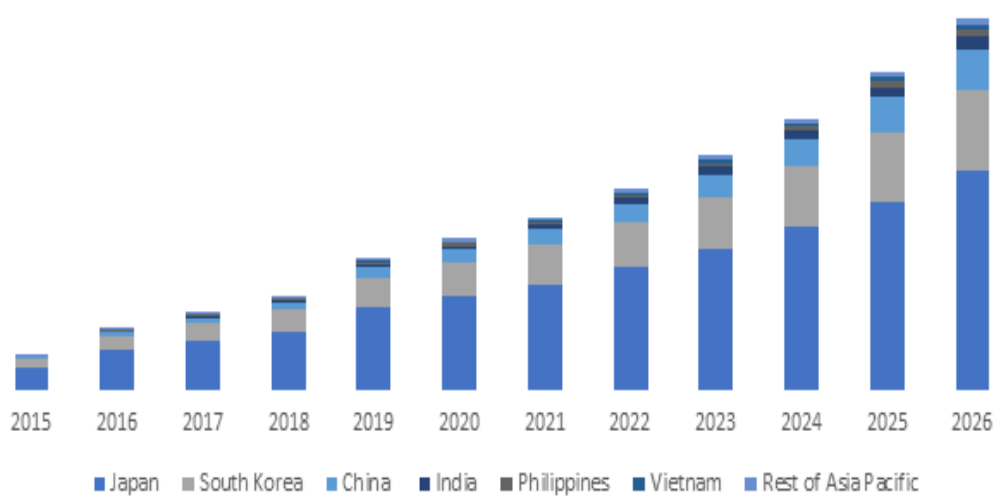

Fig. 2: Fuel cell market in Asia (adopted from [13]) 
According to China's renewable energy curtailment data in 2018, based on alkaline or proton exchange membrane electrolysis technology (collectively referred to as low-temperature electrolysis technology), about 1.855 million tons of hydrogen can be produced, which is far greater than the 143,600 tons of hydrogen used in fuel cell transportation and power generation [15]. It can be seen that the scale of application of hydrogen energy in the fuel cell field is difficult to match the volume of surplus renewable energy power. At present, hydrogen is still mainly used in the chemical market to synthesize important chemical products such as ammonia and methanol. The main uses and consumption of hydrogen in the chemical market in China in 2015 are shown in fig. 3 [12].

Therefore, taking advantage of the huge demand for hydrogen in the chemical market, transforming surplus renewable energy into major chemical products, and injecting it into the chemical market through P2X technology is an effective way to solve renewable energy consumption shortly [14]. Combining with the current main application channels of hydrogen energy in the chemical market, the following four types of electrochemical technologies will be mainly selected to analyze electricity to ammonia, electricity to methane, electricity to methanol, and electricity gasoline.

\section{Comparative study}

$\mathrm{P} 2 \mathrm{X}$ is a concept that has emerged in recent years. It refers to converting electrical energy into hydrogen through a hardware system with electricity-to-hydrogen as the core, combined with subsequent chemical processes to generate bulk chemical products such as ammonia, methane, methanol, and gasoline [16].

\section{Electricity to ammonia technology}

At present, the relatively mature technology route of electric-to-gasoline is low-temperature electrolysis for electric-to-hydrogen conversion through carbon monoxide hydrogenation and Fischer-Tropsch reaction to synthesize gasoline. There are two main reactions: water electrolysis to produce hydrogen; the other is carbon monoxide hydrogenation and Fischer-Tropsch synthetic oil. Due to the complex composition of gasoline, the main component is octane $\mathrm{C}_{8} \mathrm{H}_{1}$, so in the reaction equation and the following analysis, replace it with octane that is similar to its calorific value:

At present, the more mature technical route of electrotransformation is as follows: firstly, electrotransfer hydrogen through an electrolytic cell, and then synthesize ammonia from nitrogen and hydrogen through the Haber ammonia synthesis reactor. The basic process is shown in fig. 4. The reactions involved are mainly hydrogen production by electrolysis of water [17] as the Haber synthesis of ammonia reaction [18]. The specific reaction equation is as follows:

$$
\begin{aligned}
\mathrm{H}_{2} \mathrm{O} & \rightarrow \mathrm{H}_{2}+\frac{1}{2} \mathrm{O}_{2}, \Delta \mathrm{H}_{298 \mathrm{k}}^{0}=285.8 \mathrm{~kJ} / \mathrm{mol} \ldots \ldots . . \\
\mathrm{N}_{2}+3 \mathrm{H}_{2} & \leftrightarrow 2 \mathrm{NH}_{3}+\frac{1}{2} \mathrm{O}_{2}, \Delta \mathrm{H}_{298 \mathrm{k}}^{0}=-92.4 \mathrm{~kJ} / \mathrm{mol} . .
\end{aligned}
$$

It can be seen from the loading values of the soil nutrient indicators on each principal component in table 3 that on the first principal component, the coefficients of organic matter, total nitrogen, and total phosphorus $(>0.75)$ are significantly greater than other nutrient indicators, that is, the first principal component Represents the comprehensive nutrients of the soil. In contrast, the second principal component has a large positive correlation with available phosphorus $(\mathrm{r}=0.839)$ and hydrolyzable alkali nitrogen $(\mathrm{r}=0.795)$, and a large negative correlation with soil $\mathrm{pH}(\mathrm{r}=-$ 0.736); that is, the second principal component mainly reflects the supply status of soil available phosphorus and available nitrogen; the third principal component has a large positive correlation coefficient with total soil potassium and available potassium ( $r=0.643$, $r=0.853)$, It shows that the third principal component mainly reflects the nutritional status of soil potassium [15].

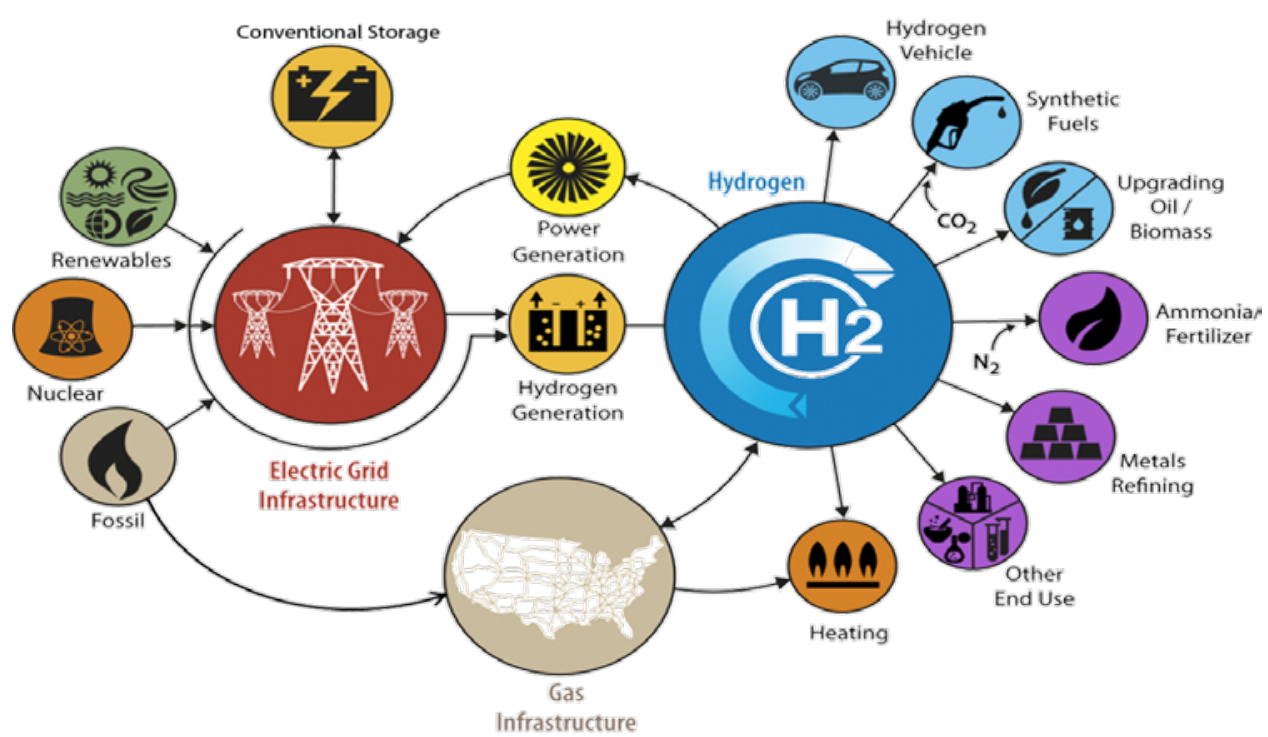

Fig. 3: Application pathways of hydrogen (adopted from [17]) 


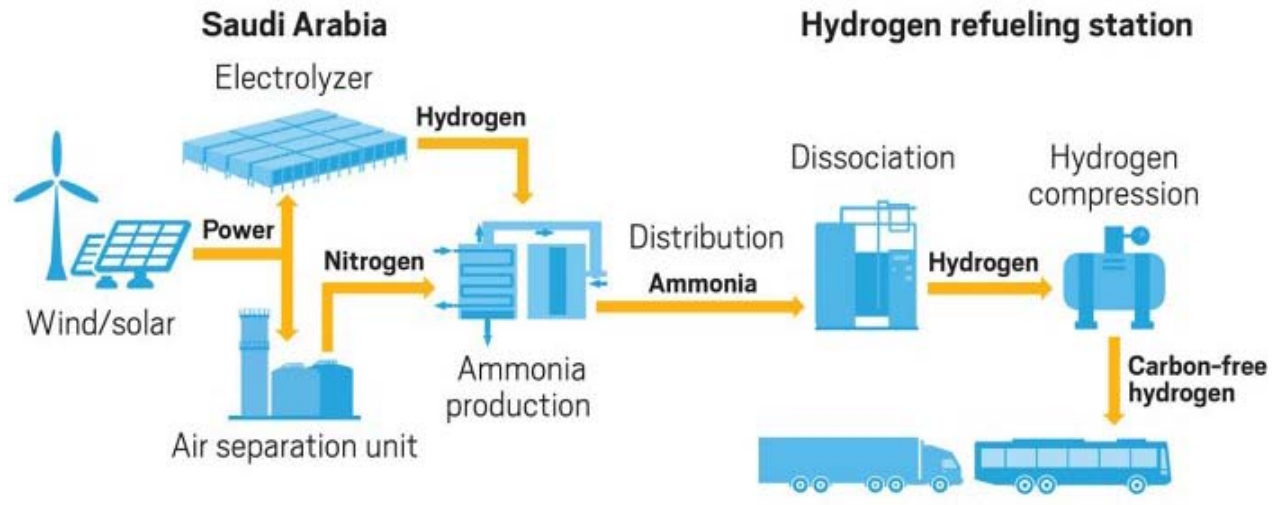

Fig. 4: Flow chart of power-to-ammonia (adopted from [16])

There are three main technical routes for hydrogen production by electrolysis: alkaline, proton exchange membrane, and high-temperature solid oxide [17]. The first two technical routes are also called low-temperature electrolysis, and they have been commercialized, and the energy efficiency of electricity-to-hydrogen conversion can reach $60 \%$ to $70 \%$. On the other hand, high-temperature solid oxides are expected to increase the energy efficiency of electricity-to-hydrogen conversion to more than $85 \%$ under high-temperature $\left(600-800{ }^{\circ} \mathrm{C}\right)$ conditions. Therefore, it is also called hightemperature electrolysis, but the technology is not yet fully mature [15]. Haber has three main technical routes for ammonia synthesis according to different catalysts and reaction processes: iron-based catalysts, ruthenium-based catalysts, and $\mathrm{Co}_{3} \mathrm{Mo}_{3} \mathrm{~N}$ catalysts [18]. The iron-based catalyst process is the most mature; the general reaction temperature is $450-525^{\circ} \mathrm{C}$, the reaction pressure is $15-32 \mathrm{MPa}$, and the energy efficiency can reach about $67 \%$ [19]. In recent years, to save energy and increase production, some scholars have studied ammonia synthesis based on ruthenium-based catalysts and $\mathrm{Co}_{3} \mathrm{Mo}_{3} \mathrm{~N}$ catalysts under reaction conditions below $400{ }^{\circ} \mathrm{C}$ and $10 \mathrm{MPa}$, but they still face problems such as higher catalyst prices or slower reaction rates [20].

According to the different reactants, two main types of direct electrotransamination reaction are the following ones. Commercial low-temperature electricity-to-hydrogen energy efficiency $\eta$ EL is about $60 \%$, and Haber's ammonia energy efficiency $\eta_{\text {нв }}$ is about $67 \%$. The electricity consumption for electricity-to-ammonia conversion is $\mathrm{W}_{\mathrm{P} 2 \mathrm{~A}}=12 \mathrm{kWh} / \mathrm{kg}$, and the overall energy efficiency is $43 \%$. When the raw material pure water is calculated at $\mathrm{C}_{\mathrm{H} 20}=0.002 \$ / \mathrm{kg}$, nitrogen is calculated at $\mathrm{C}_{\mathrm{N} 2}=0.12 \$ / \mathrm{kg}$, and ammonia is calculated at $\mathrm{C}_{\mathrm{NH} 3}=0.5 \$ / \mathrm{kg}$, the marginal electricity price of surplus renewable energy needs to be $\mathrm{C}_{\mathrm{P} 2 \mathrm{~A}}=0.04 \$ / \mathrm{kWh}$, this technical route is economically feasible. The specific calculation equation is as follows:

$$
\begin{gathered}
\mathrm{W}_{\mathrm{P} 2 \mathrm{~A}}=\mathrm{W}_{\mathrm{EL}}+\mathrm{W}_{\mathrm{HB}}=\frac{3 \mathrm{M}_{\mathrm{H}_{2}} \mathrm{LHV}_{\mathrm{H}_{2}}}{2 \mathrm{M}_{\mathrm{N}_{2}} \eta_{\mathrm{EL}}}+\left(\frac{\mathrm{LHV}_{\mathrm{NH}_{3}}}{\eta_{\mathrm{HB}}}-\frac{3 \mathrm{M}_{\mathrm{H}_{2}}}{2 \mathrm{M}_{\mathrm{NH}_{3}}} \mathrm{LHV}_{\mathrm{H}_{2}}\right) \ldots \text { (3) } \\
\mathrm{C}_{\mathrm{P} 2 \mathrm{~A}}=\frac{\left(\mathrm{C}_{\mathrm{NH}_{3}}-\frac{\mathrm{M}_{\mathrm{N}_{2}}}{2 \mathrm{M}_{\mathrm{NH}_{3}}} C_{\mathrm{N}_{2}}\right)-\frac{\mathrm{MH}_{2} \mathrm{O}}{2 \mathrm{M}_{\mathrm{NH}_{3}}} \mathrm{CH}_{2} \mathrm{O}}{\mathrm{W}_{\mathrm{P} 2 \mathrm{~A}}} \ldots \text { (4) }
\end{gathered}
$$

In the equation, $\mathrm{M}_{\mathrm{N} 2}=28 \mathrm{~g} / \mathrm{mol}, \mathrm{M}_{\mathrm{H} 2}=2 \mathrm{~g} / \mathrm{mol}, \mathrm{M}_{\mathrm{NH} 3}=17 \mathrm{~g} / \mathrm{mol}, \mathrm{M}_{\mathrm{H} 20}=18 \mathrm{~g} / \mathrm{mol}$ are the molar masses of nitrogen, hydrogen, ammonia and water respectively; $\mathrm{LHV}_{\mathrm{H} 2}=33.3 \mathrm{kWh} / \mathrm{kg}, \mathrm{LHV}_{\mathrm{NH} 3}=5.2 \mathrm{kWh} / \mathrm{kg}$ are the low calorific values of hydrogen and ammonia, respectively [22].

According to the blue paper, assess the future application potential of hydrogen energy in fuel cell vehicles, distributed power generation, and other fields, and consider the most optimistic situation: in the transportation field, based on fuel cell buses, the hydrogen consumption per $100 \mathrm{~km}$ is $8 \mathrm{~kg}$, and the average annual mileage is $70000 \mathrm{~km}$; in the field of distributed power generation, with a fuel cell power generation efficiency of $60 \%$, the application scale of hydrogen energy in the fuel cell field in 2020 is shown in fig. 2[23].

The conversion floor is designed with oblique columns, and the installation quality control requirements are high: due to the architectural layout requirements, the surrounding steel-concrete columns began to slope outward at $2 \mathrm{~F}$ floor level, and they were restored to an upright state at the $4 \mathrm{~F}$ floor level. Inward folding line shape, high-quality control requirements for lifting and installation.

In July 2018, the German ThyssenKrupp Group announced plans to build a 20 MW water electrolysis plant+50 t/d ammonia plant in Port Lincoln in southern Australia to realize the conversion of renewable energy ammonia [24]. In the future, it plans to further expand the scale to $120 \mathrm{MW}$ water electrolysis $+300 \mathrm{t} / \mathrm{d}$ synthetic ammonia.

In addition, in June 2018, Shunhe Township Industrial Park, Leibo County, Liangshan Prefecture, Sichuan Province, planned to build a 300,000 t/a surplus hydropower electrolysis hydrogen production and ammonia synthesis project with a construction period of 20 mo.

\section{Electricity to methane technology}

Statistics from the National Bureau of Statistics show that the industrial natural gas consumption in 2015 was 123.45 billion $\mathrm{m}^{3}$ [25]. With 87\% of natural gas as methane, it is about 77.597 million tons of methane. The main purpose of methane is to use natural gas and coal gas as fuel. As a chemical raw material, methane can produce acetylene, carbon black, nitrochloromethane, carbon disulfide, monochloromethane, methylene chloride, chloroform, carbon tetrachloride, and hydrocyanic acid. However, most of our teachers have participated in training courses at various levels, and very few have participated in the training of class teachers. Thus, there is a big gap in the training of class teachers. At present, the more mature technical route of electro-to-methane conversion is to synthesize methane through the hydrogenation of carbon dioxide through the electrolysis cell for electrolysis. The reactions involved mainly include the electrolysis of water to produce hydrogen; the other is the hydrogenation of carbon dioxide to synthesize methane [26].

$$
\mathrm{CO}_{2}+4 \mathrm{H}_{2} \leftrightarrow \mathrm{CH}_{4}+2 \mathrm{H}_{2} \mathrm{O}, \Delta \mathrm{H}_{298 \mathrm{k}}^{0}=-165 \mathrm{~kJ} / \mathrm{mol} \ldots . . \text { (5) }
$$

Considering the source of carbon dioxide, it has become a trend in recent years to produce bio-natural gas based on surplus electricity and biogas. This technology converts the surplus electric energy into hydrogen energy through an electrolytic cell and then hydro mechanizes the carbon dioxide in the biogas through the methanation reaction to produce biological natural gas. The technological process is shown in fig. 5[27]. 


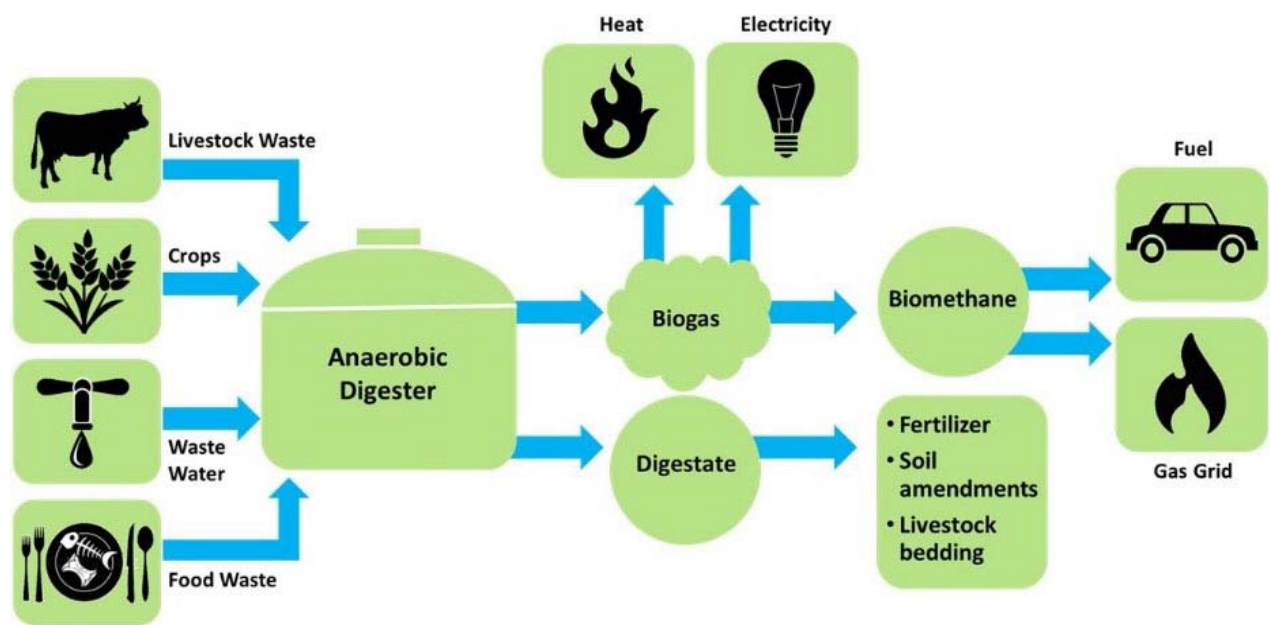

Fig. 5: Flow chart of biogas to natural gas (adopted from [13])

According to the different catalysts and reaction processes, there are three main technical routes for the hydrogenation of carbon dioxide to synthesize methane, corresponding to three metal catalysts as iron, nickel, and ruthenium [27]. Iron is cheap and easy to obtain. It was used in industry in the early stage, but its activity and selectivity were low, the reaction temperature was high, and it was easy to accumulate and inactivate carbon during use, so it was gradually eliminated. At present, nickel catalysts are used on a large scale in the industry. The general reaction temperature is $300 \sim 400{ }^{\circ} \mathrm{C}$, the reaction pressure is $1 \mathrm{bar}(1 \mathrm{bar}=100 \mathrm{kPa})$, and the corresponding energy efficiency is up to $81.8 \%$ [28]. However, the nickel catalyst is very sensitive to arsenic and sulfur, and a small amount of sulfur in the reactant will cause the catalyst to be poisoned and deactivated. Some researchers have recently paid attention to ruthenium catalysts to obtain higher activity and selectivity under low-temperature conditions $\left(90^{\circ} \mathrm{C}\right)$, but its high price limits its industrial application. In addition, the hydrogenation of carbon dioxide to synthesize methane is accompanied by many side reactions, which are more sensitive to reaction conditions, catalysts, additives, and carriers [29].

Commercial low-temperature electricity-to-hydrogen energy efficiency $\eta_{\mathrm{EL}}$ is about $60 \%$, and carbon dioxide hydrogenation to synthesize methane energy efficiency $\eta_{\mathrm{CH} 4}$ is about $81.8 \%$ [30]. Therefore, the electricity consumption for electricity-to-methane conversion is $\mathrm{W}_{\mathrm{P} 2 \mathrm{CH} 4}=28 \mathrm{kWh} / \mathrm{kg}$, and the overall energy efficiency is $50 \%$. When the raw material pure water is calculated at $\mathrm{C}_{\mathrm{H} 20}=0.002 \$ / \mathrm{kg}$ and methane is calculated at $\mathrm{C}_{\mathrm{CH} 4}=0.8$ $\$ / \mathrm{kg}$, surplus renewable energy needs to be below the marginal electricity price $\mathrm{C}_{\mathrm{P} 2 \mathrm{CH} 4}=0.06 \$ / \mathrm{kWh}$. Therefore, this technical route is economically feasible. The specific calculation equation is as follows:

$$
\begin{aligned}
& \mathrm{W}_{\mathrm{P} 2 \mathrm{~A}}=\mathrm{W}_{\mathrm{EL}}+\mathrm{W}_{\mathrm{CH} 4}=\frac{4 \mathrm{M}_{\mathrm{H}_{2}} \mathrm{LHV}_{\mathrm{H}_{2}}}{\mathrm{M}_{\mathrm{CH}_{4}} \eta_{\mathrm{EL}}}+\left(\frac{\mathrm{LHV}_{\mathrm{CH}_{4}}}{\eta_{\mathrm{CH}_{4}}}-\frac{4 \mathrm{M}_{\mathrm{H}_{2}}}{\mathrm{M}_{\mathrm{CH}_{4}}} \mathrm{LHV}_{\mathrm{H}_{2}}\right) \ldots . .
\end{aligned}
$$

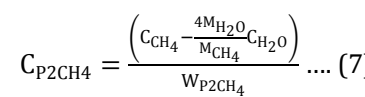

The water quality standards and technical requirements for using recycled water for various purposes are the starting point for using recycled water. Such standards are regulated by special reclaimed water regulations in the United States or health and environmental laws [31]. Technical standards for water quality, treatment technology, pipe network construction, etc., for various purposes and supervision procedures for water treatment, water distribution, water equipment, and environmental and health issues are very detailed. For example, for the intersection of reclaimed water and drinking water in the pipe network system, the United States requires a careful inspection every four years under the premise of strict marking to ensure that the reclaimed water and drinking water will not mix. Reclaimed water projects that replenish groundwater require monitoring wells and other methods to prevent groundwater pollution. The health department supervises the legality of sewage utilization, that is, the application of water quality standards, regulations, and other relevant laws [32].

In the equation, $\mathrm{M}_{\mathrm{H} 2}=2 \mathrm{~g} / \mathrm{mol}, \mathrm{M}_{\mathrm{CH} 4}=16 \mathrm{~g} / \mathrm{mol}, \mathrm{M}_{\mathrm{H} 2 \mathrm{O}}=18 \mathrm{~g} / \mathrm{mol}$ are the molar masses of hydrogen, methane, and water, respectively; $\mathrm{LHV} \mathrm{H}_{2}=33.3$ $\mathrm{kWh} / \mathrm{kg}, \mathrm{LHV}_{\mathrm{CH} 4}=13.9 \mathrm{kWh} / \mathrm{kg}$ is the low calorific values of hydrogen and methane, respectively [31].

Multiple myeloma is often misdiagnosed as lumbar degenerative disease, lumbar muscle strain, osteoporosis, nutritional anemia, etc. The onset of multiple myeloma is relatively insidious, the clinical manifestations are diverse, and the first symptoms are different. About half of the patients are already at an advanced stage when they are diagnosed. Most patients with bone and low back pain first go to the orthopedics, rheumatology, and immunology department or a massage doctor; those with renal impairment will go to the nephrology department for treatment; few patients think of going to the hematology department [17].

At present, in the planning process of China's villages and towns, they often ignore the characteristics of different rural areas or fail to pay attention to the characteristics of rural infrastructure [2]. As a result, the planning and layout of China's villages and towns are similar and unable to highlight the characteristics of villages and towns in different regions. It is also difficult to meet the wishes and demands of the local rural areas so that our villages and towns' traditional factors and characteristics are gradually decreasing. For example, the cave dwellings and semi-cave dwellings in China's central and western regions are very characteristic buildings and are quite representative. These ancient and traditional farmhouses are infiltrated by scientific principles and effectively use surface heat [7]. They are relatively warm in winter and cool in summer. They have the basic characteristics of energy-saving and comfort and are unique in shape and beautiful. On the contrary, many rural areas have transformed; although they look glamorous, they lack functionality and features [9].

In January 2016, the Mega-Store project (Methane Gas Storage for Renewable Energy) was launched by the Danish University of Science and Technology (DTU) and Lemvig Biogas Plant, which converts wind power into methane gas through a biogas plant, which is then transported to 
natural gas transmission In the net [32]. The first step of the project plan is to convert excess wind power into hydrogen through electrolysis; the second step is to react hydrogen and carbon dioxide in a biogas plant to generate methane gas and water. Since the concentration of carbon dioxide in biogas is as high as $35 \%$, the biogas plant has become an ideal place for collecting carbon dioxide gas. The current test facility of the Lemvig Biogas Plant has produced $24 \mathrm{~m}^{3}$ of biogas within $24 \mathrm{~h}$. The project will continue to expand in scale and continue in Funen's NGF Nature Energy project in the next few years [19].

\section{Electricity to methanol technology}

China is a major methanol producer country [17]. The current total methanol production capacity is 69.76 million t/a. By 2020, China's methanol production capacity will exceed 100 million t/a. Methanol is the second-largest chemical product downstream of hydrogen $(24 \%)$ in the chemical industry and can be converted into most industrial products (i.e. formaldehyde, methylamine, olefins, etc.). Methanol is a clean and high-quality fuel used as an internal combustion engine (ICE) fuel in the energy field, which is cleaner than gasoline [11, 29, 33]. Methanol gasoline has been used in many provinces, such as Shanxi, China M85/M15 methanol gasoline. Also, it can be mentioned that there are national standards, and the market price is close to that of gasoline. Secondly, the chemical properties of methanol are easy to convert between different energy forms efficiently. Onsite reforming of methanol to hydrogen is considered an important hydrogen energy acquisition channel for hydrogen refueling stations in the future [34]. Methanol fuel cells are also important research in the current energy field. Direction [35].

The improved model-predictive direct torque control method proposed in this work can obtain three voltage vectors that need to be controlled by value function optimization through the optimization vector selector, effectively reducing the optimization calculation amount of model-predictive direct torque control [36]. For control delay On the impact of system performance, delay compensation control can significantly reduce the current ripple and torque ripple caused by the control delay. By adding the constraint of the number of switching times to the value function of MPDTC, the weighting factor of the switching frequency can be increased. Reducing the switching frequency of the inverter but at the same time will increase the current distortion rate. Simulation and experimental results show that the flux linkage obtained by the full-order flux linkage observer can accurately track its given value, and the improved MPDTC has a good dynamic and static performance of the inverter and can effectively reduce the switching frequency of the inverter [18].

Since 2013, smart homes have been on fire, but at that time, many people believed that smart homes had not entered the lives of the public. With the rapid development of smart technology and the update and iteration of smart products, various smart home platforms have emerged, various smart solutions have begun to emerge one after another, and the smart home system has been further implemented [9]. In 2018, smart homes will no longer stay at the conceptual level. The maturity of artificial intelligence and Internet of Things technologies has promoted smart homes' development from single-product intelligence to system intelligence. As a result, smart homes are constantly cultivating consumer habits and have great potential [18].

At present, the more mature technical route of electro-to-methanol is based on low-temperature electrolysis for the electro-to-hydrogen synthesis of methanol through the hydrogenation of carbon dioxide. Thus, the reaction involved mainly has two parts: the electrolysis of water to produce hydrogen; the other is the hydrogenation of carbon dioxide to synthesize methanol [17].

$$
\mathrm{CO}_{2}+3 \mathrm{H}_{2} \leftrightarrow \mathrm{CH}_{3} \mathrm{OH}+\mathrm{H}_{2} \mathrm{O}, \Delta \mathrm{H}_{298 \mathrm{k}}^{0}=-49.5 \mathrm{~kJ} / \mathrm{mol} .
$$

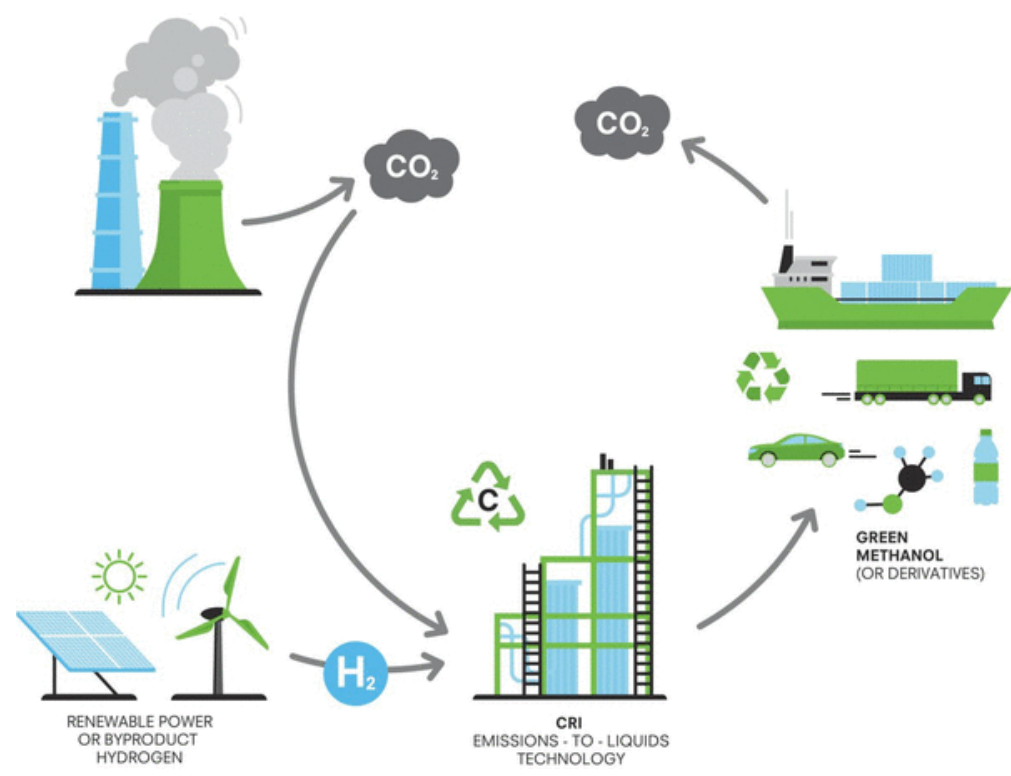

Fig. 6: Flow chart of low-temperature power-to-methanol (adopted from [34])

The main methanol synthesis catalysts currently used are zinc-chromium $(\mathrm{ZnO} / \mathrm{Cr} 2 \mathrm{O} 3)$ and copper-based $\left(\mathrm{CuO} / \mathrm{ZnO} / \mathrm{Al}_{2} \mathrm{O}_{3}\right)$. $\mathrm{However}$, when the above catalyst is directly applied to the hydrogenation of carbon dioxide, the water generated by the reaction will cause the deactivation of the copper-based catalyst. Therefore, it is necessary to develop a new type of catalyst system. The general operating conditions of copper-based catalysts are reaction temperature of $250^{\circ} \mathrm{C}$ and reaction pressure of $5 \mathrm{Mpa}$ [33]. At present, there is no mature catalyst system and process that can efficiently convert carbon dioxide and hydrogen to methanol, and the unit yield of synthetic methanol is generally less than 80\% [36].

Commercial low-temperature electricity-to-hydrogen energy efficiency $\eta_{\mathrm{EL}}$ is about $60 \%$, and carbon dioxide hydrogenation to methanol energy

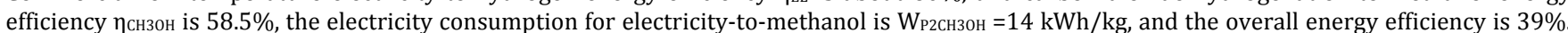
When the raw material pure water is calculated at $\mathrm{C}_{\mathrm{H} 20}=0.002 \$ / \mathrm{kg}$ and methanol is calculated at $\mathrm{C}_{\mathrm{CH} 3 \mathrm{OH}}=0.3 \$ / \mathrm{kg}$, the electricity price of surplus 
renewable energy needs to be below the marginal electricity price Сргснзон $_{2} 0.04 \$ / \mathrm{kWh}$. This technical route is economically feasible[37]. The specific calculation equation is as follows:

$$
\begin{aligned}
& \mathrm{W}_{\mathrm{P} 2 \mathrm{CH}_{3} \mathrm{OH}}=\mathrm{W}_{\mathrm{EL}}+\mathrm{W}_{\mathrm{CH}_{3} \mathrm{OH}}=\frac{3 \mathrm{M}_{\mathrm{H}_{2}} \mathrm{LHV}_{\mathrm{H}_{2}}}{\mathrm{M}_{\mathrm{CH}_{3} \mathrm{OH} \eta_{\mathrm{EL}}}}+\left(\frac{\mathrm{LHV}_{\mathrm{CH}_{3} \mathrm{OH}}}{\eta_{\mathrm{CH}_{3} \mathrm{OH}}}-\frac{3 \mathrm{M}_{\mathrm{H}_{2}}}{\mathrm{M}_{\mathrm{CH}_{3} \mathrm{OH}}} \mathrm{LHV}_{\mathrm{H}_{2}}\right) \ldots . . \text { (9) } \\
& \mathrm{C}_{\mathrm{P} 2 \mathrm{CH}_{3} \mathrm{OH}}=\frac{\left(\mathrm{C}_{\mathrm{CH}_{3} \mathrm{OH}-}-\frac{3 \mathrm{M}_{\mathrm{H}_{2}} \mathrm{O}}{\mathrm{M}_{\mathrm{CH}_{3} \mathrm{OH}}} \mathrm{C}_{\mathrm{H}_{2} \mathrm{O}}\right)}{\mathrm{W}_{\mathrm{P} 2 \mathrm{CH}_{3} \mathrm{OH}}} \ldots . . .(10)
\end{aligned}
$$

In the equation: $\mathrm{M}_{\mathrm{H} 2}=2 \mathrm{~g} / \mathrm{mol}, \mathrm{M}_{\mathrm{CH} 3 \mathrm{OH}}=32 \mathrm{~g} / \mathrm{mol}, \mathrm{M}_{\mathrm{H} 2 \mathrm{O}}=18 \mathrm{~g} / \mathrm{mol}$ are the molar masses of hydrogen, methanol and water respectively; LHV $\mathrm{H}_{2}=$ $33.3 \mathrm{kWh} / \mathrm{kg}, \mathrm{LHV}_{\mathrm{CH} 3 \mathrm{OH}}=5.5 \mathrm{kWh} / \mathrm{kg}$ is the low calorific value of hydrogen and methanol respectively [31].

In 2011, Svartsengi, near Grindavik, Iceland, built the world's largest renewable energy power-to-methanol plant (The George Olah Renewable Methanol Plant) [38]. As of 2015, the annual output of renewable methanol reached 4,000 tons, and the annual carbon dioxide absorption was 5,500 tons [39].

In 2018, the Lanzhou New District planned to build liquid solar fuel electrolysis of water for hydrogen production and carbon dioxide hydrogenation to synthesize methanol technology development projects [17]. The main technical route of this project is to use the clean electric energy of photovoltaic power plants to electrolyze water to produce hydrogen and then combine hydrogen and enriched carbon dioxide to produce methanol. The project plans to construct an annual output of 1,000 tons of methanol, about 1500 tons of carbon dioxide, and an annual demand of about 200 tons of hydrogen [21].

\section{Electricity to gasoline technology}

The National Bureau of Statistics results shows that China's gasoline consumption in 2017 was 122 million tons. Gasoline is an important fuel for automobiles and ignition-type internal combustion engines. In addition, the electricity-to-gasoline technology converts carbon dioxide into gasoline, which is of great value for replacing fossil fuels and has important demonstration significance for environmental protection, sustainable development, and national energy security [22].

Statistics from the National Bureau of Statistics of China show that the national synthetic ammonia production in 2017 was 49,462,600 tons [13], and the annual growth rate was $4.7 \%$. In the chemical industry, ammonia is the largest downstream chemical product of hydrogen in the industrial sector (hydrogen consumption accounts for 47\%), and ammonia is the world's second-largest production chemical after sulfuric acid [11]. It is used to make ammonia and nitrogen fertilizers (urea, Ammonium bicarbonate, etc.), compound fertilizers, nitric acid, ammonium salts, soda ash, etc., are widely used in chemical, light industry, fertilizer, pharmaceutical, synthetic fiber, and other fields. In the energy sector, the high calorific value of ammonia is $22.5 \mathrm{MJ} / \mathrm{kg}$, equivalent to that of fossil fuels. Therefore, anhydrous ammonia can be directly burned in internal combustion engines and ammonia fuel cells for transportation, power generation, and other fields [14].

At present, there are two main reaction conditions for the Fischer-Tropsch reaction: high-temperature Fischer-Tropsch, the reaction temperature is $330 \sim 350{ }^{\circ} \mathrm{C}$, generally use iron-based catalyst; low-temperature Fischer-Tropsch, the reaction temperature is 200 - $250{ }^{\circ} \mathrm{C}$, the reaction pressure is 20-30 bar, use iron or cobalt-based catalysts [19].

$$
8 \mathrm{CO}+17 \mathrm{H}_{2} \leftrightarrow \mathrm{C}_{8} \mathrm{H}_{18}+8 \mathrm{H}_{2} \mathrm{O}, \Delta \mathrm{H}_{298 \mathrm{k}}^{0}=-1259.38 \mathrm{~kJ} / \mathrm{mol}
$$

Commercial low-temperature electricity-to-hydrogen energy efficiency $\eta_{\mathrm{EL}}$ is about $60 \%$, and carbon monoxide hydrogenation synthesis gasoline energy efficiency $\eta_{\mathrm{FT}}$ is about $70 \%$. The electricity consumption of electricity-to-gasoline (in octane) is $\mathrm{W}_{\mathrm{P} 2 \mathrm{G}}=18 \mathrm{kWh} / \mathrm{kg}$, and the overall energy efficiency is $50.6 \%$ [31]. When the raw material pure water is calculated at $\mathrm{C}_{\mathrm{H} 20}=0.002 \$ / \mathrm{kg}$, carbon monoxide at $\mathrm{C}_{\mathrm{CO}}=0.4 \$ / \mathrm{kg}$, and gasoline at $\mathrm{C}_{\mathrm{C} 8 \mathrm{H} 18}=2.1 \$ / \mathrm{kg}$, the surplus renewable energy electricity price needs to be at the marginal electricity price $\mathrm{C}_{\mathrm{P} 2 \mathrm{G}}=0.08 \$ / \mathrm{kWh}$, this technical route is economically feasible. The specific calculation equation is as follows:

$$
\begin{aligned}
& \mathrm{W}_{\mathrm{P} 2 \mathrm{G}}=\mathrm{W}_{\mathrm{EL}}+\mathrm{W}_{\mathrm{FT}}=\frac{17 \mathrm{M}_{\mathrm{H}_{2}} \mathrm{LHV}_{\mathrm{H}_{2}}}{\mathrm{M}_{\mathrm{C}_{8} \mathrm{H}_{18} \eta_{\mathrm{EL}}}}+\left(\frac{\mathrm{LHV}_{\mathrm{C}_{8} \mathrm{H}_{18}}}{\eta_{\mathrm{FT}}}-\frac{17 \mathrm{M}_{\mathrm{H}_{2}}}{\mathrm{M}_{\mathrm{C}_{8} \mathrm{H}_{18}}} \mathrm{LHV}_{\mathrm{H}_{2}}-\frac{8 \mathrm{M}_{\mathrm{CO}}}{\mathrm{M}_{\mathrm{C}_{8} \mathrm{H}_{18}}} \mathrm{LHV}_{\mathrm{CO}}\right) \ldots \\
& \mathrm{C}_{\mathrm{P} 2 \mathrm{G}}=\frac{\left(\mathrm{C}_{\mathrm{C}_{8} \mathrm{H}_{18}}-\frac{17 \mathrm{M}_{\mathrm{H}_{2} \mathrm{O}} \mathrm{O}}{\mathrm{M}_{8} \mathrm{H}_{18}} \mathrm{C}_{\mathrm{H}_{2} \mathrm{O}}\right)-\frac{8 \mathrm{M}_{\mathrm{CO}}}{\mathrm{M}_{\mathrm{C}_{8}} \mathrm{H}_{18}} \mathrm{C}_{\mathrm{CO}}}{\mathrm{W}_{\mathrm{P} 2 \mathrm{G}}}
\end{aligned}
$$

The equation: $\mathrm{M}_{\mathrm{CO}}=28 \mathrm{~g} / \mathrm{mol}$ is the molar mass of hydrogen, octane, water, and carbon monoxide, respectively; $\mathrm{LHV}_{\mathrm{H} 2}=33.3 \mathrm{kWh} / \mathrm{kg}$, $\mathrm{LHV}_{\mathrm{C} 8 \mathrm{H} 18}$ $=12.08 \mathrm{kWh} / \mathrm{kg}, \mathrm{LHV}_{\mathrm{co}}=2.81 \mathrm{kWh} / \mathrm{kg}$ are gas and carbon monoxide Low calorific value [32].

It should be noted that the electro-gasoline conversion process based on low-temperature electrolysis needs to be combined with carbon monoxide, which has certain carbon emissions, and the energy-saving and emission-reduction effect is significantly reduced compared with the route mentioned above; at the same time, the Fetou synthesis reaction for realizing gasoline synthesis is a short-chain molecular synthesis [40]. The process of long-chain molecules, the investment scale, technology, and operation and maintenance of the synthetic equipment are more difficult than the three types mentioned above P2X technical routes. The research in this article only compares the marginal electricity prices and does not fully reflect the economics of the technical route. Detailed analysis still needs more in-depth industry research and analysis [12].

\section{Comparative analysis of P2X technology}

Based on the above research on the four electrochemical technologies, the following compares the four electrochemical technologies of electricity to ammonia, electricity to methane, electricity to methanol, and electricity to gasoline from the five aspects of energy efficiency, electricity consumption, marginal electricity price, equivalent output, and market share [9]. The analysis is shown in table 3 , where the equivalent output is calculated from China's renewable energy curtailment data in 2018 [17].

The construction of the project adopts the information method. To ensure safety during the excavation of the foundation pit, the foundation pit must be monitored. Any problems should be reported and analyzed in time, and corresponding rescue measures should be taken to prevent accidental damage and deformation of the foundation pit. The safety level of each section of the project is Class II [15]. According to the regulations, the allowable value of foundation pit deformation is $0.4 \%$, the pre-warning value of foundation pit slope deformation is set to $25 \mathrm{~mm}$, and the control value is set to $35 \mathrm{~mm}[19]$. 
It can be seen that among the four electrochemical technologies, the energy efficiency of electricity to methane and electricity to gasoline is relatively high (50\%), and the energy efficiency of electricity to methanol is the lowest (39\%) [17]. The energy efficiency, reaction conditions, and material heating value of each electrochemical technology are relatively high (50\%). Factors are related. The theoretical energy efficiency of synthetic ammonia, methane, methanol, and oil calculated by chemical equations is $88.49 \%, 83.48 \%$, 88.09\%, and 78.17\%. However, due to synthetic ammonia and methanol's high reaction pressure requirements, the electricity consumption in the larger synthesis process, overall energy efficiency are lower [39]. Comparing the marginal electricity price index, based on the market prices of four chemical products, taking Sichuan Province, a major hydropower and chemical industry province, as an example, the electricity price for large industries is about 0.5 yuan/kWh, and the electricity chemical technology is temporarily not economical at this price. Considering that the electricity price of the surplus hydropower policy is 0.245 yuan/kWh, the electricity-to-oil and electricity-to-amino conversion is inherently economical at this price, while the electricity-tomethane and electricity-to-methanol technical routes need to improve energy efficiency further or reduce policy electricity prices to be profitable [17]. Consider the impact of electrochemical technology on the chemical market. For example, if all surplus renewable energy is converted into chemical products, $17.18 \%$ of ammonia will be replaced by green ammonia, and electro-to-ammonia will greatly impact the original chemical market [13].

Furthermore, the social benefits of clean electrochemical technology using surplus renewable energy in coal saving and environmental protection are analyzed [7]. From table 4, based on China's renewable energy curtailment data in 2018, in terms of coal saving, replacing coal-to-gasoline with electricity-to-gasoline will save coal consumption to the greatest extent (22.85 million tce); in terms of environmental protection, replacing coal with electricity-to-ammonia Ammonia conversion will minimize carbon emissions (emission reduction of 39.1 million tCO ${ }_{2}$ ). In summary, electricity-to-gasoline conversion has the most economic and coal-saving benefits, while electricity-to-ammonia conversion has environmental benefits and market share, two important development directions for future electrochemical technology [41].

\section{DISCUSSION}

In addition to the current mature technology that uses low-temperature electrolysis to produce hydrogen as a link to connect electricity to hydrogen and subsequent chemical processes, in recent years, with the maturity of high-temperature electrochemical technology, some electrochemical processes can also be realized through direct electrochemical reactions [3]. Such a synthesis process is mainly realized by high-temperature solid oxide batteries (SOEC), collectively referred to as high-temperature electrochemical technology in this article. The following is an overview and analysis of four high-temperature electrochemical technology routes: electricity-to-ammonia, electricity-to-methane, electricity-to-methanol, and electricity-to-gasoline [18].

\section{High-temperature electricity to ammonia technology}

Some researchers have devoted themselves to realizing direct electrotransamination through electrochemical methods [9]. According to different electrolyte states, there are four main technical routes for direct electro-ammonia transfer: liquid electrolyte (corresponding to room temperature reaction temperature), molten salt electrolyte (reaction temperature $180 \sim 500^{\circ} \mathrm{C}$ ), cross-linked membrane (reaction temperature $400 \sim 650{ }^{\circ} \mathrm{C}$ ), and solid electrolyte (reaction temperature is $600 \sim 750{ }^{\circ} \mathrm{C}$ ) [42]. Among them, the solid electrolyte is divided into proton conductive electrolyte and oxygen ion conductive electrolyte. Commonly used economic analysis methods usually consider the primary investment cost of equipment, the variable cost of materials, and additional operation and maintenance costs. Since the price of hydrogen energy conversion equipment is declining rapidly, and the investment in synthesis equipment does not account for a high proportion of the entire life cycle, this article synthesizes the synthesis product's terminal price and marginal power consumption [20]. Furthermore, it calculates the marginal electricity price afforded during the conversion process to compare the economic differences of different technical routes [32].

The molten salt electrolyte and the proton-conducting electrolyte carry out equation 14, while the liquid electrolyte and the oxygen ion-conducting electrolyte carry out equation 15 [43].

At present, the technology of direct electrochemical synthesis of ammonia is relatively immature. Due to the limitation of catalysts, the reaction rate of direct electrotransformation of ammonia is relatively low (the highest is only $3.3 \times 10-8 \mathrm{~mol} / \mathrm{s} \cdot \mathrm{cm}^{2}$ ), the Faraday efficiency is the highest. Up to $90.4 \%$, the corresponding energy efficiency is about $65 \%$ [44].

$$
\begin{gathered}
\mathrm{N}_{2}+3 \mathrm{H}_{2} \leftrightarrow 2 \mathrm{NH}_{3} \ldots .(14) \\
\mathrm{N}_{2}+3 \mathrm{H}_{2} \mathrm{O} \leftrightarrow 2 \mathrm{NH}_{3}+\frac{3}{2} \mathrm{O}_{2} \ldots(15)
\end{gathered}
$$

\section{High-temperature electricity to methane technology}

A schematic diagram of the direct synthesis of methane by co-electrolysis of carbon dioxide and water-based on high-temperature solid oxide batteries is shown in fig. 7, where the green arrow represents the direction of co-electrolysis to synthesize methane [45].

The abnormal noise of the car is caused by two parts, which come from the tire bearing and the transmission differential. The diagnosis of this type of failure is relatively difficult. When we need to repair it, we must patiently check and diagnose it one by one to eliminate the failure [46]. 


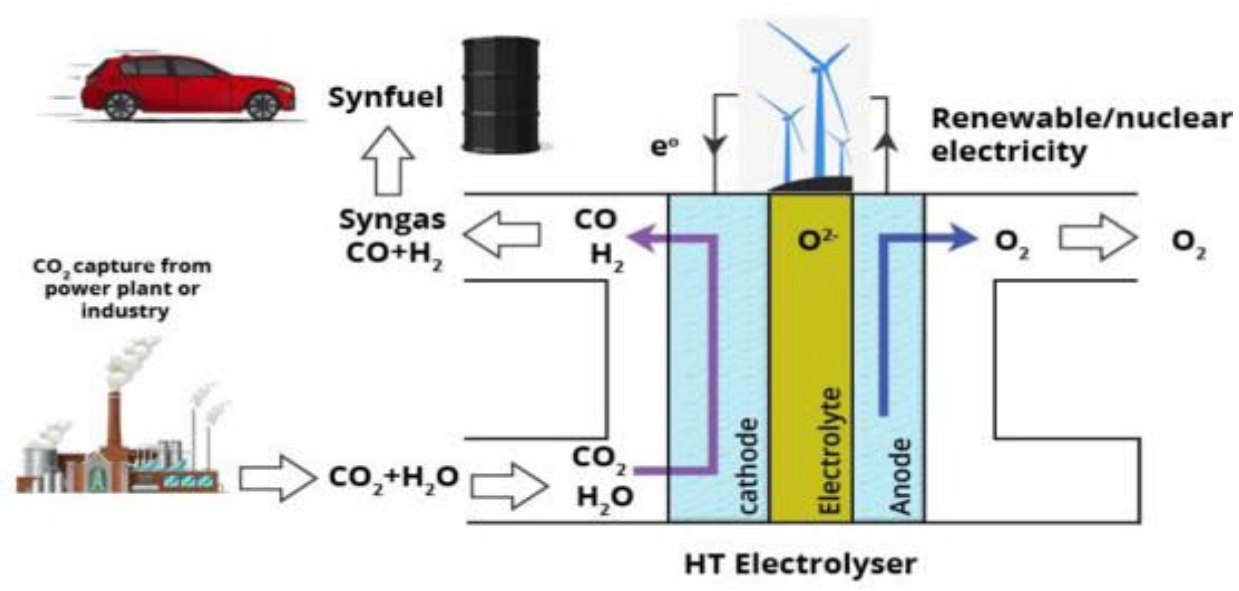

Fig. 7: Schematic diagram of co-electrolysis of $\mathrm{CO}_{2}$ and $\mathrm{H}_{2} \mathrm{O}$ (adopted from [44])

The core reactions of the co-electrolysis process are:

$$
\mathrm{CO}_{2}+2 \mathrm{H}_{2} \mathrm{O} \leftrightarrow \mathrm{CH}_{4}+2 \mathrm{O}_{2} \ldots .(16)
$$

The reaction temperature is $650^{\circ} \mathrm{C}$, the reaction pressure is about 20 bar, and the energy efficiency is about $84 \%$ [46]. However, the technology of high-temperature solid oxide batteries is facing immaturity and high cost [19].

\section{High-temperature electricity to methanol technology}

To further improve the energy efficiency of methanol conversion, Risø National Laboratory in Denmark and Idaho National Laboratory in the United States have proposed a technical route with high-temperature co-electrolysis technology as the core and conducted experimental tests [47]. The solid oxide electrolytic cell is used to co-electrolyze water and carbon dioxide at $800{ }^{\circ} \mathrm{C}$ and 25 bar, and at the same time, generate hydrogen and carbon monoxide synthesis gas. As shown in fig. 8, the electrolysis energy efficiency is higher than 95\%, compared with the energy efficiency of lowtemperature electrolysis is significantly increased [48]. The core reactions of the high-temperature co-electrolysis process are:

$$
\mathrm{CO}_{2}+\mathrm{H}_{2} \mathrm{O} \leftrightarrow \mathrm{H}_{2}+\mathrm{CO}+\mathrm{O}_{2} \ldots(17)
$$

In addition, the use of the energy cascade complementary characteristics of co-electrolysis and methanolization to achieve a combined cycle of energy and material can further reduce the system's overall energy consumption. However, due to the stack attenuation during the long-term operation of SOEC, electrode materials and catalyst improvements, battery (stack) operation, and system analysis are still in their infancy. The US CERAMATEC company is carrying out related research along this technical route $[49,50]$.

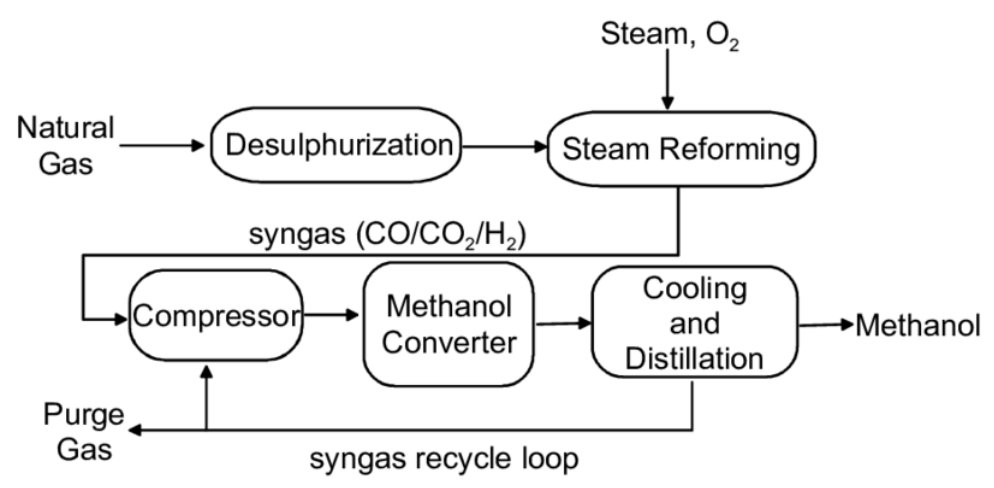

Fig. 8: Flow chart of high-temperature power-to-methanol (adopted from [48])

\section{High-temperature electricity to gasoline technology}

The high-temperature co-electrolysis method is based on the co-electrolysis of carbon dioxide and water based on high-temperature solid oxide batteries and simultaneously generates hydrogen and carbon monoxide synthesis gas [51]. First, the core reaction is shown in equation 17, and the synthesis gas is synthesized by Fischer-Tropsch synthesis to generate gasoline and other fuels, As shown in fig. 9 [52]. At the same time, the hightemperature solid oxide battery can also work in the fuel cell power generation mode (SOFC) to feed power to the grid [53]. 
Indirect Conversion Synthetic Fuels Manufacturing Processes

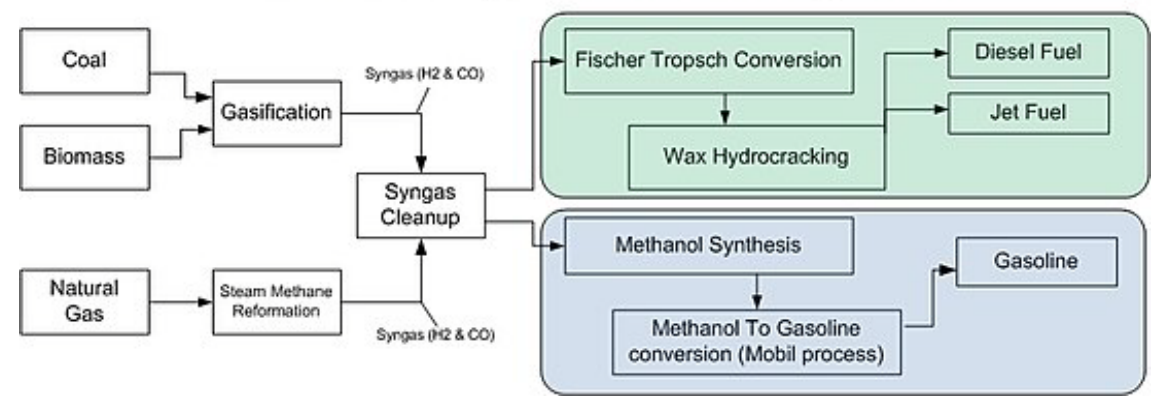

Fig. 8: Flow chart of high-temperature power-to-gasoline (adopted from [49])

However, it needs to be pointed out that the high-temperature electrolysis and co-electrolysis technologies are still in the early stages of industrialization. With increased equipment investment and operation and maintenance costs, technical bottlenecks in materials and catalysts still need to be overcome [54]. In the future, with the further maturity of technology, the energy consumption level and economic efficiency of the electrochemical technology route based on high-temperature electrolysis are expected to be further improved [55].

\section{CONCLUSION}

Due to the small scale of application of hydrogen energy in the fuel cell field at this stage, it is difficult to match China's surplus renewable energy volume. Electrochemical technology is an effective way to solve the problem of renewable energy curtailment in the near future. This article mainly focuses on four main electrochemical technologies, namely electricity-to-ammonia, electricity-to-methane, electricity-to-methanol, and electricityto-gasoline, from the perspectives of market size, technical route, economy, and demonstration projects. The current mature technical route is the indirect synthesis method of low-temperature electrolysis plus subsequent traditional chemical processes. On this basis, the five major technical and economic indicators of energy efficiency, power consumption, marginal electricity price, equivalent output, and market share of the four electrochemical technologies are compared and analyzed. Among them, in terms of energy efficiency, electricity-to-methane and electricity-togasoline technologies have higher comprehensive energy efficiency (50\%), and electricity-to-methanol technologies have the lowest comprehensive energy efficiency (39\%); in terms of economy, electricity-to-gasoline technology is the most economical, but the system equipment investment is large, and the technical risks are still high. Because of the electricity price of the surplus renewable energy policy, electricity-to-ammonia is inherently economical, while electricity-to-methane and methanol need to be further improved in energy efficiency or to reduce electricity prices; in terms of market size, based on the current volume of surplus renewable energy electricity, electricity-to-ammonia will have an impact on the original market The greatest impact (17.18\%). Based on this analysis and calculation based on the coal consumption and carbon emission indicators of traditional coal chemical technology, electricity-to-gasoline has the most economic and coal-saving benefits, while electricity-to-ammonia is the most environmentally friendly and has the market share, and is expected to become two of the future electrochemical technologies. The most important development direction. In recent years, there have been technical routes such as the direct synthesis of chemical products based on electrochemical reactions or the use of high-temperature co-electrolysis to generate synthesis gas instead of low-temperature electrolysis directly. This technical route unifies the hydrogen production and synthesis processes and helps realize the overall system's small size. The overall energy efficiency has improved, but technical bottlenecks such as electrochemical catalyst selection, slow reaction rate, and immature devices still need to be overcome. This is an important direction for basic theoretical research and industrial research and development in the future.

\section{FUNDING}

Nil

\section{AUTHORS CONTRIBUTIONS}

All the authors have contributed equally.

\section{CONFLICT OF INTERESTS}

Declared none

\section{REFERENCES}

1. Zhou Q, Wang N, Ran L, Shen H, Lv Q, Wang M. Cause analysis on wind and photovoltaic energy curtailment and prospect research in. China Electr Power. 2016;49:7-12.

2. Feng Y, Wang S, Sha Y, Ding Q, Yuan J, Guo X. Coal power overcapacity in China: province-level estimates and policy implications. Resour Conserv Recy. 2018 Oct 1;137:89-100. doi: 10.1016/j.resconrec.2018.05.019.

3. Schiebahn S, Grube T, Robinius M, Tietze V, Kumar B, Stolten D. Power to gas: technological overview, systems analysis and economic assessment for a case study in Germany. Int J Hydr Energy. 2015 Apr 6;40(12):4285-94. doi: 10.1016/j.ijhydene.2015.01.123.

4. Lehner M, Tichler R, Steinmüller H, Koppe M. Power-to-gas: technology and business models. Springer; 2014 Jul 18.

5. Qadrdan M, Abeysekera M, Chaudry M, Wu J, Jenkins N. Role of power-to-gas in an integrated gas and electricity system in Great Britain. Int J Hydr Energy. 2015 May 11;40(17):5763-75. doi: 10.1016/j.ijhydene.2015.03.004.

6. Petipas F, Brisse A, Bouallou C. Model-based behaviour of a high-temperature electrolyser system operated at various loads. J Power Sources. 2013 Oct 1;239:584-95. doi: 10.1016/j.jpowsour.2013.03.027.

7. Kopp M, Coleman D, Stiller C, Scheffer K, Aichinger J, Scheppat B. Energiepark Mainz: technical and economic analysis of the worldwide largest power-to-gas plant with PEM electrolysis. Int J Hydr Energy. 2017 May 11;42(19):13311-20. doi: 10.1016/j.ijhydene.2016.12.145.

8. Khani H, Farag HEZ. Optimal day-ahead scheduling of power-to-gas energy storage and gas load management in wholesale electricity and gas markets. IEEE Trans Sustain Energy. 2017 Oct 27;9(2):940-51. doi: 10.1109/TSTE.2017.2767064.

9. Frank M, Deja R, Peters R, Blum L, Stolten D. Bypassing renewable variability with a reversible solid oxide cell plant. Appl Energy. 2018 May 1;217:101-12. doi: 10.1016/j.apenergy.2018.02.115. 
10. Meng X, Gu A, Wu X, Zhou L, Zhou J, Liu B, Mao Z. Status quo of China hydrogen strategy in the field of transportation and international comparisons. Int J Hydr Energy. 2020 Dec 2.

11. Kendall M. Fuel cell development for New Energy Vehicles (NEVs) and clean air in China. Prog Nat Sci Mater Int. 2018 Apr 1;28(2):113-20. doi: 10.1016/j.pnsc.2018.03.001.

12. Zhao F, Mu Z, Hao H, Liu Z, He X, Victor Przesmitzki S, Ahmad Amer A. Hydrogen fuel cell vehicle development in China: an industry chain perspective. Energy Technol. 2020 Nov;8(11). doi: 10.1002/ente.202000179, PMID 2000179.

13. Scopus Database. Available from: https://www.scopus.com.search/form.uri?display=basic\#basic. [Last accessed on 10 Apr 2021]

14. Wiley Database. Available from: https://www.wiley.com/en-ir. [Last accessed on 10 Apr 2021]

15. Springer database. Available from: https://www.springer.com/gp. [Last accessed on 10 Apr 2021]

16. Taylor and Francis database. Available from: https://taylorandfrancis.com. [Last accessed on 10 Apr 2021]

17. Liu F, Zhao F, Liu Z, Hao H. The impact of fuel cell vehicle deployment on road transport greenhouse gas emissions: the China case. Int J Hydr Energy. 2018 Dec 13;43(50):22604-21. doi: 10.1016/j.ijhydene.2018.10.088.

18. Feng X. Methanol ammonia and new energy economy. Chemical Industry Publisher; 2010. p. 55.

19. Rashid MM, Al Mesfer MK, Naseem H, Danish M. Hydrogen production by water electrolysis: a review of alkaline water electrolysis, PEM water electrolysis and high-temperature water electrolysis. Int J Eng Adv Technol. 2015 Feb;4(3):2249.

20. Valera Medina A, Xiao H, Owen Jones M, David WIF, Bowen PJ. Ammonia for power. Prog Energy Combust Sci. 2018 Nov 1;69:63-102. doi: 10.1016/j.pecs.2018.07.001.

21. Tovazhnyanskyy L, Klemes JJ, Kapustenko P, Arsenyeva O, Perevertaylenko O, Arsenyev P. Optimal design of welded plate heat exchanger for ammonia synthesis column: an experimental study with mathematical optimization. Energies. 2020 Jan;13(11):2847. doi: $10.3390 /$ en13112847.

22. Banares Alcantara R, Dericks III G, Fiaschetti M, Grunewald P, Lopez JM, Tsang E, Yang A, Ye L, Zhao S. Analysis of islanded ammonia-based energy storage systems. University of Oxford; 2015 Sep.

23. Bicer Y, Khalid F. Life cycle environmental impact comparison of solid oxide fuel cells fueled by natural gas, hydrogen, ammonia and methanol for combined heat and power generation. Int J Hydr Energy. 2020 Jan 29;45(5):3670-85. doi: 10.1016/j.ijhydene.2018.11.122.

24. Aziz M, Oda T, Morihara A, Kashiwagi T. Combined nitrogen production, ammonia synthesis, and power generation for efficient hydrogen storage. Energy Procedia. 2017 Dec 1;143:674-9. doi: 10.1016/j.egypro.2017.12.745.

25. Bongartz D, Dore L, Eichler K, Grube T, Heuser B, Hombach LE, Robinius M, Pischinger S, Stolten D, Walther G, Mitsos A. Comparison of lightduty transportation fuels produced from renewable hydrogen and green carbon dioxide. Appl Energy. 2018 Dec 1;231:757-67. doi: 10.1016/j.apenergy.2018.09.106.

26. Bicer Y, Dincer I. Life cycle evaluation of hydrogen and other potential fuels for aircrafts. Int J Hydr Energy. 2017 Apr 20;42(16):10722-38. doi: 10.1016/j.ijhydene.2016.12.119.

27. Adnan MA, Kibria MG. Comparative techno-economic and life-cycle assessment of power-to-methanol synthesis pathways. Appl Energy. 2020 Nov 15;278. doi: 10.1016/j.apenergy.2020.115614, PMID 115614.

28. Eggemann L, Escobar N, Peters R, Burauel P, Stolten D. Life cycle assessment of a small-scale methanol production system: A power-to-fuel strategy for biogas plants. J Cleaner Prod. 2020 Oct 20;271. doi: 10.1016/j.jclepro.2020.122476, PMID 122476.

29. Huang H, Samsun RC, Peters R, Stolten D. Greener production of dimethyl carbonate by the power-to-fuel concept: a comparative technoeconomic analysis. Green Chem. 2021;23(4):1734-47. doi: 10.1039/D0GC03865B.

30. Bargiacchi E, Antonelli M, Desideri U. A comparative assessment of power-to-fuel production pathways. Energy. 2019 Sep 15;183:1253-65. doi: 10.1016/j.energy.2019.06.149.

31. Bellotti D, Sorce A, Rivarolo M, Magistri L. Techno-economic analysis for the integration of a power to fuel system with a CCS coal power plant. J CO2 Util. 2019 Oct 1;33:262-72. doi: 10.1016/j.jcou.2019.05.019.

32. Cheng ZH. Research progress of methanation of carbon monoxide and carbon dioxide. Chem Ind Eng Prog. 2007;9.

33. Peters R, Baltruweit M, Grube T, Samsun RC, Stolten D. A techno economic analysis of the power to gas route. J CO2 Util. 2019 Dec 1;34:616-34. doi: 10.1016/j.jcou.2019.07.009.

34. Decker M, Schorn F, Samsun RC, Peters R, Stolten D. Off-grid power-to-fuel systems for a market launch scenario- A techno-economic assessment. Appl Energy. 2019 Sep 15;250:1099-109. doi: 10.1016/j.apenergy.2019.05.085.

35. Energy DY. Production, conversion, storage, conservation, and coupling. Springer Science+Business Media; 2012 Jan 26.

36. Salami HA. A comparative life cycle assessment of energy use in major agro-processing industries in Nigeria. J Energy Res Rev. 2019 Sep 21:1. doi: $10.9734 /$ jenrr/2019/v3i430102.

37. Bromberg L, Cheng WK. Methanol as an alternative transportation fuel in the US: options for sustainable and/or energy-secure transportation. Cambridge, MA: Sloan Automotive Laboratory, Massachusetts Institute of Technology; 2010 Nov 28.

38. Pearson RJ, Turner JW, Eisaman MD, Littau KA. Extending the supply of alcohol fuels for energy security and carbon reduction [SAE technical paper]. 2009 Nov 2.

39. Ohtani J, Sakamoto T, Wada M, Faizal HM, Yokomori T, Ueda T. Experimental study on a methanol auto-thermal reforming for compact reformer. Mech Eng J. 2016;3(2):15-00069. doi: 10.1299/mej.15-00069.

40. Yeh P, Chang CH, Shih N, Yeh N. Durability and efficiency tests for direct methanol fuel cell's long-term performance assessment. Energy. 2016 Jul 15;107:716-24. doi: 10.1016/j.energy.2016.04.091.

41. Zhang Y, Sun Q, Deng J, Wu D, Chen S. A high activity Cu/ZnO/Al2O3 catalyst for methanol synthesis: preparation and catalytic properties. Appl Cat A. 1997 Sep 25;158(1-2):105-20. doi: 10.1016/S0926-860X(96)00362-6.

42. Beigzadeh M, Pourfayaz F, Ghazvini M, Ahmadi MH. Energy and exergy analyses of solid oxide fuel cell-gas turbine hybrid systems fed by different renewable biofuels: A comparative study. J Cleaner Prod. 2021;280. doi: 10.1016/j.jclepro.2020.124383, PMID 124383.

43. Herz G, Rix C, Jacobasch E, Muller N, Reichelt E, Jahn M, Michaelis A. Economic assessment of power-to-liquid processes- influence of electrolysis technology and operating conditions. Appl Energy. 2021 Jun 15;292. doi: 10.1016/j.apenergy.2021.116655, PMID 116655.

44. Schemme S, Breuer JL, Köller M, Meschede S, Walman F, Samsun RC, Peters R, Stolten D. H2-based synthetic fuels: A techno-economic comparison of alcohol, ether and hydrocarbon production. Int J Hydr Energy. 2020 Feb 14;45(8):5395-414. doi: 10.1016/j.ijhydene.2019.05.028.

45. Parigi D, Giglio E, Soto A, Santarelli M. Power-to-fuels through carbon dioxide Re-Utilization and high-temperature electrolysis: A technical and economical comparison between synthetic methanol and methane. J Cleaner Prod. 2019 Jul 20;226:679-91. doi: 10.1016/j.jclepro.2019.04.087.

46. Zhang Y, Yuan Z, Margni M, Bulle C, Hua H, Jiang S, Liu X. Intensive carbon dioxide emission of coal chemical industry in China. Appl Energy. 2019 Feb 15;236:540-50. doi: 10.1016/j.apenergy.2018.12.022.

47. Wang X, Wang W, Qiao M, Wu G, Chen W, Yuan T, Xu Q, Chen M, Zhang Y, Wang X, Wang J, Ge J, Hong X, Li Y, Wu Y, Li Y. Atomically dispersed Au1 catalyst towards an efficient electrochemical synthesis of ammonia. Sci Bull. 2018 Oct 15;63(19):1246-53. doi: 10.1016/j.scib.2018.07.005. 
48. Murakami T, Nishikiori T, Nohira T, Ito Y. Investigation of anodic reaction of electrolytic ammonia synthesis in molten salts under atmospheric pressure. J Electrochem Soc. 2005 Mar 25;152(5):D75. doi: 10.1149/1.1874752.

49. Xu G, Liu R, Wang J. Electrochemical synthesis of ammonia using a cell with a nafion membrane and $\mathrm{SmFe} 0.7 \mathrm{Cu} 0.3-\mathrm{x} \mathrm{Ni} \times \mathrm{O} 3(\mathrm{x}=\theta 0.3$ ) cathode at atmospheric pressure and lower temperature. Sci China S B: Chemistry. 2009 Aug 1;52:1171-5.

50. Jensen SH, Graves C, Mogensen M, Wendel C, Braun R, Hughes G, Gao Z, Barnett SA. Large-scale electricity storage utilizing reversible solid oxide cells combined with underground storage of CO2 and CH4. Energy Environ Sci. 2015 Jul 29;8(8):2471-9. doi: 10.1039/C5EE01485A.

51. Jensen SH, Larsen PH, Mogensen M. Hydrogen and synthetic fuel production from renewable energy sources. Int J Hydr Energy. 2007 Oct 1;32(15):3253-7. doi: 10.1016/j.ijhydene.2007.04.042.

52. Hartvigsen J, Elangovan S, Frost L, Nickens A, Stoots CM, O’Brien JE, Herring JS. Carbon dioxide recycling by high-temperature co-electrolysis and hydrocarbon synthesis. ECS Trans. 2008 May 2;12(1):625-37. doi: 10.1149/1.2921588.

53. Kolodziejczyk B. Unsettled issues concerning the use of green ammonia fuel in ground vehicles [SAE technical]. 2021 Feb 15.

54. Gutierrez Martin F, Rodriguez Anton LM. Power-to-SNG technologies by hydrogenation of CO2 and biomass resources: a comparative chemical engineering process analysis. Int J Hydrogen Energy. 2019 May 17;44(25):12544-53. doi: 10.1016/j.ijhydene.2018.09.168.

55. Wang L, Perez Fortes M, Madi H, Diethelm S, Marechal Fherle JV, Marechal F. Optimal design of solid-oxide electrolyzer based power-tomethane systems: A comprehensive comparison between steam electrolysis and co-electrolysis. Applied Energy. 2018 Feb 1;211:1060-79. doi: 10.1016/j.apenergy.2017.11.050. 